\title{
Změny kinetických charakteristik odrazu volejbalistů mládežnických kategorií v průběhu šesti měsíců
}

\section{The changes of an attack jump kinetic characteristics of young volleyball players during six months}

\author{
Pavel Korvas, Jaroslav Šamšula
}

Fakulta sportovních studií Masarykovy univerzity, Brno

\begin{abstract}
Abstrakt
$V$ př́spěvku se autoři zabývají změnami čtyř důležitých ukazatelů charakterizujících odraz při útočném odrazu dvou skupin hráčù volejbalu mládežnických kategorií vrcholové úrovnè. Testování proběhlo $v$ časovém intervalu šesti měsícu․ Byla hodnocena průmèrná síla odrazu, maximální impulz síly, čas odrazu a čas dosažení maximálního impulzu sily. Ve všech sledovaných ukazatelích byla lepší skupina juniorů. Vètšího nárůstu absolutních hodnot dosáhla skupina kadetů: u průmèrné hodnoty síly celého odrazu o $17,4 \%$ a $v$ čase realizace celého odrazu o 16,6\%. Hodnota maximálního impulzu síly se zvýšila o 3,9\% a čas dosažení této hodnoty se zkrátil o $14,4 \%$. U juniorů byla největši zmèna zaznamenána ve zkrácení času potřebného $k$ dosažení maximálního impulzu síly o 12,5\% a současně u zkrácení doby celého odrazu o 10,6\%. Prưmèrná síla odrazu se u této skupiny zvýšila o 9,2\%. Obě skupiny absolvovali v uvedeném časovém intervalu vysoký objem zatížení, junioři 342 hodin a kadeti 211 hodin. Rozdíly ve výsledcích a velikosti změn jsou predevším důsledkem biologického dospivání, délky pravidelného tréninku, trénovanosti i výkonnosti jednotlivých skupin.
\end{abstract}

\begin{abstract}
The authors compare four variables of an attack jump between two groups of volleyball players, juniors and cadets. We observed during six months average strength of rebound, maximal impulse of strength, the time of whole rebound and the time reaching maximal impulse of strength. The group of juniors had better results for every parameter but cadets reached the highest improvement. The younger group gets to positive changes in average strength during rebound by $17,4 \%$, and for the time of whole rebound about $16,6 \%$. Maximal impulse of strength was increased by 3,9\% and the time reaching maximal impulse of strength was shorter $14,4 \%$. Juniors reached smaller changes than cadets, for average strength during rebound 9,2\%, maximal impulse of strength was increased by $12,5 \%$ and the time of whole rebound about 10,6\%. The value of maximal impulse of strength was worst by 5,2\%. The both groups realized training programme of a very high quality, juniors 342 hours and cadets 211 hour of trainings load. The differences in results and value of changes are consequences of maturity, time of regular training process and performance level of our groups.
\end{abstract}

Klíčová slova: $\quad$ smeč, odraz, hráči, volejbal, prưměrná síla odrazu, maximální impulz odrazu, čas odrazu, čas dosažení maximálního impulzu síly odrazu

Key words: $\quad$ attack jump, rebound, volleyball players, average strength of rebound, maximal impulse of rebound, time of rebound, time to reach of maximal impulse of strength.

\section{Úvod}

Volejbal je hra s komplexním pohybovým projevem, zatěžující většinu svalů a svalových skupin těla, s velkými požadavky na fyzickou, technickou, taktickou i psychickou připravenost hráčů. Pohybovou činnost při volejbalu lze charakterizovat jako krátkodobé, často opakované úseky pohybové aktivity, které se stř́ídají s různě dlouhým přerušením. Zatížení při hře má střídavou intenzitu, od nízké po maximální (Sheppard 2008, Stanganelli 2008, Gabbett 2006 aj.). Podle Havlíčkové (1993) je pro herní výkon hráče důležitý rozvoj rychlosti (reakční i realizační), síly (dynamického charakteru), obratnosti (koordinace) a pohyblivosti. 
Rozhodující činnosti se odehrávají v maximální možné výšce nad zemí, výšce, kterou hráči dosahují vertikálním výskokem, což zvyšuje význam odrazových schopností dolních končetin. Proto je při rozvoji kondičních schopností kladen důraz na sílu a zejména na dynamickou sílu (Dobrý 1988). Pro rychlostně silové sportovní výkony je dynamická síla jednou z významných proměnných určujících výsledek pohybové činnosti (Cacek 2007). Podle Havlíčkové (1993) by měl volejbalista dosáhnout při výskoku minimální výšky $330 \mathrm{~cm}$, ovšem hodnoty vlastního výskoku českých hráčů v utkání tomu nenasvědčují a pohybují se od $41,1 \mathrm{~cm}$ do $55,9 \mathrm{~cm}$. Výšku výskoku ovlivňuje především tělesná hmotnost, výška hráče, procentuální zastoupení rychlých vláken a dostatečná pohyblivost v hlezenním kloubu. Nejhorších výkonů ve výskoku dosahují obvykle libera a nahrávači, nejlepších blokaři a smečaři (Gabbett 2007, Duncan 2006, Haník 2008 aj.).

Ve volejbalu musí hráči dokonale technicky zvládnout několik druhů základních skoků, při kterých můžeme rozlišovat různou techniku, účel, celkové provedení, př́ípravu na skok, koordinaci celého těla apod. (Haník 2004, 2008, Zapletalová 1997, 2001 aj.). Výskok zásadně ovlivňuje kvalitu hry hráče na síti, jeho úspěšnost $\mathrm{v}$ obranné i útočné fázi hry. Jedním z předpokladu úspěchu v utkání znamená realizovat kvalitní silný útok. Hlavní formou útoku v moderní hře je smeč. $\mathrm{K}$ tomu je potřeba provést vysoký výskok, který je umožněn kvalitním a silným odrazem dolními končetinami. Efektivita výskoku při smeči odpovídá transferu energie $\mathrm{v}$ kinetickém řetězci začínajícím od dolní končetiny $\mathrm{k}$ horním končetinám a závisí na pohyblivosti, síle a koordinaci. Celý akt smeče je zahájen rozběhem, po kterém následuje vertikální skok. Rozběh umožňuje získat horizontální hybnost, kterou je nutné transformovat do vertikální hybnosti s následným letem (Machado 2002).

Odrazové schopnosti a dovednosti jsou rozvíjeny vhodným tréninkem. Součástí ověření efektivity volejbalového tréninkového procesu, který je zaměřený komplexně, je periodické hodnocení úrovně odrazových schopností a dovedností (Machado 2002, Voigt 2003, Haník 2008, Marques 2008 aj.). Pro hodnocení úrovně odrazových schopností jsou obvykle využívány vertikální i horizontální skoky, testování maximální síly, silového výkonu i stupně silového rozvoje (Stone 2007, Grassgruber, Cacek 2008). Některé studie prokazují těsný vztah mezi sílou, silovým výkonem a hodnotou vertikálního skoku (např. Bobbet 1994). Síla dolních končetin je u hráčů volejbalu testována většinou pomocí motorických testů, méně často pomocí testovacích zařízení (Machado 2002, Marques 2009). Pro správnou interpretaci výsledků u daného sportovního výkonu by měl být test maximálně specifický s pohybovými strukturami, v co největší míře se shodujícími s vlastním odrazem při hře. Existuje řada testů, které mají shodný nebo velmi podobný průběh pohybu jako odrazy při hře. Nejčastěji se využívají skoky z místa, z rozběhu, útočný nebo obranný skok, skok z místa do dálky aj. (Marques 2008, 2009, Perič, Suchý 2010, Měkota 1983, Haník 2004, 2008). Přístrojová zařízení bývají pro testování odrazových a silových schopností využívána méně často. Mezi nejznámější používané ve volejbale patří např. desky OR6-5, AMTI (USA), trigonometrický koberec firmy Ergojump (Digitime, Finland) nebo Fitro Jumper (Fitronic, Slovensko), EMED (Novel, Německo) a další (Machado 2002, Zvonař 2010 aj.).

Jeden z mála výzkumů, ve kterém byly kvantifikovány síly odrazu dolními končetinami u elitních volejbalistů, lze nalézt u Machada (2002), který zjistil reakci podložky ve vertikálním směru při odrazu na blok ve výši 3,3 - 4,5 násobku hmotnosti těla.

\section{Cíl studie}

Analyzovat změny silových a časových ukazatelů při útočném odrazu v intervalu 6 měsíců u hráčů volejbalu, kategorií kadetů a juniorů.

\section{Metodika}

Měření byla provedena $\mathrm{v}$ průběhu soutěžního období v prosinci 2009 a na začátku přechodného období v květnu 2010. Bylo to období těsně navazující na závěr hlavního období, ve kterém stále probíhala pravidelná tréninková činnost, i když nižšího objemu a intenzity. Byla využita dynamometrická deska Fitro Force 12 (fy Fitronic, Slovensko) a náběhové plató v úrovni odrazové plochy desky. Jedná se o jednoduchou přesnou desku na měření dynamické síly dolních končetin při různém pohybu (běh, chůze, skoky). Skládá se z jedné desky, elektroniky, 12bitového AD konvertoru a softwaru pro získání a analýzu dat, ze kterých se vypočíá akcelera- 
ce, rychlosti, přemístění a výkon z křivky síly v čase. Síly jsou zaznamenávány ve vertikální i horizontální rovině. Měření probíhá bud’v nastaveném časovém úseku nebo jako jednorázový akt. Software umožňuje nastavit frekvenci záznamu impulsu síly na desku. Při výzkumu jsme využívali interval 0,001 s.

Každý sportovec po rozcvičení a zaškolení (1-2 pokusy) provedl tři pokusy útočného odrazu (smeč), ze kterých byly vypočítány průměry u vybraných parametrů. Z nabídky měřených ukazatelů byly pro hodnocení vybrány: nejvyšší hodnota maximálního impulzu síly dosaženého v průběhu odrazu, průměrný tlak vytvořený na desku v průběhu celého odrazu, doba realizace celého odrazu a doba potřebná k vytvoření maximálního impulzu síly.

Byly hodnoceny průměrné hodnoty jednotlivých ukazatelů a rozdíly mezi kategoriemi. Pro zpracování výsledků byla použita jednoduchá popisná statistika, $\mathrm{t}$-test $(\mathrm{p} \leq 0,1)$ a násobek dosažené síly dolních končetin $\mathrm{k}$ hmotnosti jedince.

\section{Charakteristika výzkumného souboru}

Byla sledována 2 družstva (junioři $[\mathrm{J}]$ a kadeti $[\mathrm{K}]$ ) rozdílná průměrným věkem, výkonností, dobou pravidelného tréninku, kvantitou i kvalitou tréninkového procesu apod. Obě družstva mají vrcholovou výkonnost a jsou mistry ČR ve svých kategoriích.

Tab. 1 Charakteristika souboru při prvním měření

\begin{tabular}{|c|c|c|c|c|c|c|c|}
\hline Kategorie & & \multicolumn{2}{|c|}{ věk } & \multicolumn{2}{c|}{ výška } & \multicolumn{2}{c|}{ hmotnost } \\
\hline & & $\mathrm{x}$ & $\mathrm{s}$ & $\mathrm{x}$ & $\mathrm{s}$ & $\mathrm{x}$ & $\mathrm{s}$ \\
\hline Kadeti & 8 & 15,9 & 0,2 & 188,9 & 6,3 & 73 & 7,5 \\
\hline Junioři & 8 & 17,6 & 0,6 & 192,4 & 5,4 & 79,3 & 3,7 \\
\hline
\end{tabular}

Tab. 2 Charakteristika souboru při druhém měření

\begin{tabular}{|c|c|c|c|c|c|c|c|}
\hline Kategorie & & \multicolumn{2}{|c|}{ věk } & \multicolumn{2}{c|}{ výška } & \multicolumn{2}{c|}{ hmotnost } \\
\hline & & $\mathrm{x}$ & $\mathrm{s}$ & $\mathrm{x}$ & $\mathrm{s}$ & $\mathrm{x}$ & $\mathrm{s}$ \\
\hline Kadeti & 8 & 16,4 & 0,4 & 188,7 & 5,6 & 73,6 & 6,9 \\
\hline Junioři & 8 & 18,1 & 0,7 & 192,8 & 5,1 & 81,0 & 4,1 \\
\hline
\end{tabular}

Základní somatometrické parametry se v krátkém časovém intervalu u juniorů i kadetů změnily minimálně, nebyl nalezen žádný statisticky významný rozdíl.

\section{Výsledky}

Ve výsledcích vybraných silových i časových ukazatelů byly zjištěny změny hodnot u obou skupin i v rozdílech mezi skupinami.

Tab.1 Výsledky prvního měření skupiny juniorů a kadetů

\begin{tabular}{|c|c|c|c|c|c|}
\hline Kategorie & & $\begin{array}{c}\text { Průměrná } \\
\text { hodnota } \\
\text { síly odrazu (N) }\end{array}$ & $\begin{array}{c}\text { Hodnota max. } \\
\text { impulzu síly (N) }\end{array}$ & $\begin{array}{c}\text { Čas celého } \\
\text { odrazu (ms) }\end{array}$ & $\begin{array}{c}\text { Čas odrazu } \\
\text { do max. impul- } \\
\text { zu síly (ms) }\end{array}$ \\
\hline Kadeti & $\mathrm{x}$ & 1641,3 & 2750,2 & 353,1 & 236,1 \\
\hline & $\mathrm{SD}$ & 110,2 & 244,8 & 33,1 & 43,4 \\
\hline Junioři & $\mathrm{x}$ & 2021,1 & 3296,9 & 310,7 & 204,7 \\
\hline & SD & 222,5 & 511,1 & 39,3 & 43,2 \\
\hline
\end{tabular}


Tab.2 Výsledky druhého měření skupiny juniorů a kadetů

\begin{tabular}{|c|c|c|c|c|c|}
\hline Kategorie & & $\begin{array}{c}\text { Průměrná hodnota } \\
\text { síly odrazu (N) }\end{array}$ & $\begin{array}{c}\text { Hodnota max. } \\
\text { impulzu síly (N) }\end{array}$ & $\begin{array}{c}\text { Čas celého } \\
\text { odrazu (ms) }\end{array}$ & $\begin{array}{c}\text { Čas odrazu do max. } \\
\text { impulzu síly (ms) }\end{array}$ \\
\hline Kadeti & $\mathrm{x}$ & 1926,5 & 2857,3 & 302,1 & 206,3 \\
\hline & SD & 175,3 & 293,5 & 27,0 & 32,2 \\
\hline Junioři & $\mathrm{x}$ & 2208,3 & 3127,5 & 276,3 & 185,1 \\
\hline & SD & 183,5 & 358,7 & 24,0 & 16,1 \\
\hline
\end{tabular}

Kadeti se zlepšili ve všech vybraných parametrech jak silových, tak i časových. U průměrné síly celého odrazu dosáhli zlepšení o $17,9 \%(\mathrm{p} \leq 0,006)$ a současně byla zkrácena i doba provedení celého odrazu o $16,6 \%$ ( $\mathrm{p} \leq 0,011)$. U hodnoty maximálního impulzu síly bylo zjištěno zlepšení o 3,9\% ( $\mathrm{p} \leq 0,288$ ), současně tato fáze odrazu byla kratší proti prvnímu měření o $14,4 \%(\mathrm{p} \leq 0,128)$. Statisticky významná zlepšení byla tedy zaznamenána jen u hodnot charakterizujících celý odraz.

Skupina juniorů zaznamenala zlepšení u tř́ ze čtyř sledovaných ukazatelů. Podobně jako u kadetů jen dvě zlepšení byla statisticky významná. U průměrné síly odrazu dosáhli hodnoty o 9,2 \% vyšší (p $\leq$ $0,088)$, současně se doba celého odrazu zkrátila o $10,6 \%(\mathrm{p} \leq 0,159)$. U průměrné hodnoty maximálního impulzu síly se junioři mírně zhoršili o $5,2 \%$ ( $\mathrm{p} \leq 0,271)$, přičemž čas pro jeho dosažení se zkrátil o $12,5 \%$ $(\mathrm{p} \leq 0,044)$.

Mezi výsledky obou skupin byly nalezeny různé rozdíly při prvním a druhém měření, vždy byli lepší junioři. Při prvním měření činily rozdíly mezi oběma kategoriemi u hodnoty průměrného odrazu $18,8 \%$ ( $\mathrm{p} \leq 0,001)$, u maximálního impulzu síly $16,6 \%(\mathrm{p} \leq 0,013)$ a u času odrazu $13,5 \%(\mathrm{p} \leq 0,024)$. Rozdíl v čase potřebném $\mathrm{k}$ dosažení maximálního impulzu síly dosáhl 15,1\% ( $\mathrm{p} \leq 0,102)$. Při druhém měření byly zjištěny u jednotlivých ukazatelů menší rozdíly. $V$ průměrné síle celého odrazu byli junioři lepší o $10,2 \%$ $(\mathrm{p} \leq 0,025)$ a v čase celého odrazu o $8,7 \%$ ( $\mathrm{p} \leq 0,098)$. Rozdíly bez statistické významnosti byly zjištěny pro hodnoty maximálního impulzu síly o velikosti $8,0 \%(\mathrm{p} \leq 0,149)$ a pro čas potřebný $\mathrm{k}$ dosažení maximálního impulzu síly o velikosti $2,7 \%(\mathrm{p} \leq 0,165)$.

Tab.3 Hodnoty síly dosažené při odrazu jako násobek hmotnosti u jednotlivých skupin

\begin{tabular}{|c|c|c|c|c|}
\cline { 2 - 5 } \multicolumn{1}{c|}{} & \multicolumn{2}{c|}{1 . měření } & \multicolumn{2}{c|}{ 2. měření } \\
\cline { 2 - 5 } \multicolumn{1}{c|}{} & junioři & kadeti & junioři & kadeti \\
\hline $\begin{array}{c}\text { rozsah průměrné síly } \\
\text { odrazu skupiny }\end{array}$ & $2,3-3,3$ & $2-2,4$ & $2,4-3,4$ & $2,3-2,9$ \\
\hline $\begin{array}{c}\text { průměrná síla } \\
\text { odrazu skupiny }\end{array}$ & 2,5 & 2,3 & 2,8 & 2,6 \\
\hline $\begin{array}{c}\text { rozsah maximálního } \\
\text { impulzu skupiny }\end{array}$ & $3,7-5,7$ & $3,2-4,1$ & $3,3-5,1$ & $3,3-4,3$ \\
\hline $\begin{array}{c}\text { průměr maximálního } \\
\text { impulzu skupiny }\end{array}$ & 4,1 & 3,8 & 4 & 3,8 \\
\hline
\end{tabular}

Relativní hodnoty průměrné síly odrazu vyjádřené násobkem hmotnosti hráčů se mezi prvním a druhým měřením zlepšily u obou skupin. Hodnoty maximálního impulzu síly zůstaly u kadetů stejné, junioři se zhoršili o $2,4 \%$, přičemž hmotnost obou skupin se významně nezměnila. Pro obě relativní hodnoty byly nalezeny významné rozdíly mezi prvním a druhým měřením u juniorů i kadetů pro hodnoty průměrné síly odrazu $\left(\mathrm{p} \leq_{\mathrm{J}} 0,039, \mathrm{p} \leq_{\mathrm{K}} 0,001\right)$. U hodnoty maximálního impulzu síly kadeti dosáhli relativní hodnoty stejné jako při prvním měření, junioři dosáhli horšího výsledku, který nebyl statisticky významný $(\mathrm{p} \leq 0,259)$. 
Rozdíly mezi kategoriemi pro obě relativní hodnoty byly poměrně malé. Při prvním měření činil rozdíl mezi juniory a kadety u průměrné síly celého odrazu $8 \%$, při druhém měření $7,1 \%$, u maximálního impulzu síly při prvním $7,3 \%$, při druhém $5 \%$. Tyto rozdíly mezi oběma kategoriemi byly statisticky významné při prvním měření pro průměrnou hodnotu celého odrazu $(\mathrm{p} \leq 0,016)$ i pro hodnotu maximálního impulzu síly $(\mathrm{p} \leq 0,085)$. Při druhém měření byl nalezen významný rozdíl jen u průměrné hodnoty celého odrazu $(\mathrm{p} \leq 0,032)$. I přes menší zhoršení juniorů $\mathrm{v}$ hodnotě maximálního impulzu síly při druhém měření dosáhli lepšího výsledku než kadeti, bez statistické významnosti rozdílů ( $\mathrm{p} \leq 0,311)$.

\section{Diskuze}

Záměrem výzkumu bylo zjistit možnosti monitorování specifických silových schopností dolních končetin při útočném odrazu u hráčů volejbalu kategorie juniorů a kadetů pomocí dynamometrické desky Fitro Force 12. Pomocí uvedeného výzkum byly kvantifikovány absolutní i relativní hodnoty vybraných silových a časových charakteristik odrazu při útočném skoku. Při dvou měřeních realizovaných v 6 měsíčním časovém intervalu byly vyhodnoceny změny odrazových schopností hráčů volejbalu dvou věkových kategorií.

Při srovnání výsledků testů jednotlivých skupin lze sledovat zlepšení ve většině sledovaných ukazatelů. I když probandi obou skupin „zestárli“ jen o půl roku, absolvovali poměrně značný tréninkový i zápasový objem zatížení. Tréninkový proces v uvedeném období mezi měřeními byl u juniorů ve výši 342 hodin, 24 zápasů mistrovských a 12 př́pravných, celkově 91 tréninkových dní a 153 tréninkových jednotek. U kadetů dosáhl objem zatížení 211 hodin, 29 mistrovských a 5 př́pravných zápasů, 89 tréninkových dní a 115 tréninkových jednotek. To znamenalo rozdíl mezi oběma skupinami v celkovém objemu tréninkového procesu 38,3\% (hodiny zatížení) a 5,5\% u zápasového zatížení.

Hráči obou skupin se zlepšili téměř ve všech sledovaných silových i časových ukazatelích, výjimkou byla hodnota maximálního impulzu síly u juniorů, kde jsme zaznamenali pokles.

Zhoršení juniorů je možné dát i do souvislosti se zhoršením nejlepšího hráče o 640 N, které významně ovlivnilo průměrný výkon skupiny. Zbývající hráči dosáhli podobných výsledků jako při prvním měření.

Kadeti i přes nižší objem tréninkového zatížení dosáhli větších zlepšení absolutních (a více významných). To dokumentují i menší rozdíly při druhém měření. Je to logické, protože tato skupina je v úvodních letech etapy specializovaného sportovního tréninku, ve kterém se začíná zvyšovat objem zatížení i procento využívaných specifických tréninkových prostředků, které tréninkový proces zintenzivňují a efektivně zvyšují úroveň specifické trénovanosti a výkonnosti (Choutka 1981, Haník 2004, Bompa 2005). U této věkové kategorie ke zlepšení více přispívá i stále probíhající intenzívní biologický vývoj, který také ovlivňuje rozvoj silových schopností jedince v tomto věku (Dovalil 2002). Kadeti se v průběhu sledování ve všech hodnotách vybraných ukazatelů mírně juniorům přibližují, protože rozdíly při druhém měření mezi oběma skupinami byly menší. Při prvním měření byly zjištěny tři významné rozdíly mezi oběma skupinami a při druhém jen dva.

U kategorie juniorů byla výše zaznamenaných zlepšení menší než u kadetů. To může znamenat zpomalování růstu trénovanosti i při vysokém objemu a kvalitě tréninkového a zápasového zatížení a postupné přibližování se individuálnímu maximu odrazových schopností a dovedností (Haník 2008, Korvas 2010). Současně již tato skupina zřejmě dosáhla vysoké úrovně techniky odrazu, jeho ekonomiky a schopnosti rychle přenést horizontální energii do odrazu vertikálním směrem, což také může ovlivnit menší úroveň zlepšení (Gabett 2006).

\section{Závěry}

Výsledky jsou úvodním šetřením dlouhodobého monitorování odrazových schopností hráčů volejbalu v etapě specifického sportovního tréninku jako důležitého faktoru výkonnosti ve volejbalu a přinesly některé důležité poznatky.

Bylo zaznamenáno předpokládané zlepšení v silových i časových ukazatelích odrazu u kategorie kadetů. Většina těchto zlepšení byla významná, což svědčí o pozitivním kombinovaném vlivu vhodného tréninku i dospívání. Kadeti jsou ve věku vysokého nárůstu trénovanosti i výkonnosti vlivem tréninkového zatížení. 
U juniorů již změny hodnot silových a časových ukazatelů prokázaly menší rozdíly jak pozitivní, tak i negativní. U této skupiny bylo zjištěno méně statisticky významných zlepšení než u kadetů. To může svědčit o zahájení dosahování individuálního maxima výkonnosti v odrazových schopnostech sledovaných hráčů.

Výzkum a výsledky přinesly cenné informace pro tréninkový proces ve volejbalu a potvrdily potřebu dalšího sledování, zaměřeného především praktickým směrem na tréninkový proces a rozvoj výbušné síly dolních končetin a odrazových schopností a dovedností hráčů.

\section{Literatura}

Amasay, Tal (2008) Static Block Jump Techniques in Volleyball: Upright versus Squat Starting Positions. J Strength Cond Res. 22(4):1242-1248.

Bartlett, R. (2009) Sports biomechanics. Milton Park, Routledge, 2 ed.,s.291.

Bobbet, M.F., VanSoest, A.J. (1994) Effect on muscle strengthening on vertical jump height: a simulation study. Med. Sci.Sports Exerc. 26, pp.1012-1020.

Bompa, T.O., Carrera, M.C. (2005) Periodization training for sports. Champaign, Human Kinetics, 259 s. Cacek, J., Lajkeb, P., Michálek, J. (2007) Trénink síly v atletice (metoda plyometrická). Atletika, Praha 4: Česká atletika s.r.o., 59, 3, od s. 17-20, 4 s.

Dovalil, J. a kol. Výkon a trénink ve sportu. Praha, Olympia, 2002.

Duncan MJ, Woodfield L, al-Nakeeb Y. (2006) Anthropometric and physiological characteristics of junior elite volleyball players. Br J Sports Med. 2006 Jul; 40(7): 649-51;

Gabbett T, Georgieff B, Anderson S, Cotton B, Savovic D, Nicholson L. (2006) Changes in skill and physical fitness following training in talent-identified volleyball players. J Strength Cond Res.; 20(1): 29-35.

Gabbett, T., Georgieff, B., (2007) Physiological and Anthropometric Characteristics of Australian Junior National, State, and Novice Volleyball Players. J Strength Cond Res 21(3): 902-908.

Grasgruber, P., Cacek, J. (2008) Sportovní geny. 1. vyd. Brno: Computer Press, 480 s.

Haník, Z. (2004) Volejbal 1. Herní dovednosti a kondice tréninku mládeže. 1. vyd. Praha: Český volejbalový svaz. $518 \mathrm{~s}$.

Haník, Z. (2008) Volejbal 2. Učební texty pro školení trenérů. 1. vyd. Praha: Olympia. 347 s.

Choutka, M. (1981) Sportovní výkon. Praha, Olympia 98 s.

Machado, D.B., Andrade, M.C., Avila, A.O.V., Fischer, B., Schlee, G.(2002) Characteristics of ground reaction forces, moments and C.O.P. during volleyball block-jumps. VIII Emed scientific meeting Kananaskis, Alberta. Canada.

Marques M.C., Tillaar R., Vescovi J.D., González-Badillo J.J. (2008) Changes in strength and power performance in elite senior female professional volleyball players during the in-season: a case study. $J$ Strength Cond Res. 2008 Jul; 22(4):1147-55.

Perič,T. (2006) Výběr sportovních talentü. Grada, Praha, $100 \mathrm{s.}$

Sheppard, J. M., Cronin, J. B., Gabbett, T. J., McGuigan, M. R., Etxebarria, N., Newton, R.U. (2008) Relative Importance of Strength, Power, and Anthropometric Measures to Jump Performance of Elite Volleyball Players. J Strength Cond Res. 22(3):758-765,

Stanganelli L.C., Dourado A.C., Oncken P., Mançan S., da Costa S.C. (2008) Adaptations on jump capacity in Brazilian volleyball players prior to the under-19 World Championship.

J Strength Cond Res.; 22(3):741-9.

Šimonek, J. (2006) Volejbal: Rozvoj koordinačních schopností. 1. vyd. Bratislava: Peter Mačura - PEEM. $92 \mathrm{~s}$.

Perič, T., Suchý, J. a kol. Identifikace sportovních talentů, Praha: Karolinum, 2010.

Stone, M.H., Stone, M., Sands, W.A. (2007) Principles and practice of resistance training. Champaign, Human Kinetics, s.374.

Voigt, H., Vetter,K. (2003) The value of strenght - diagnostic for the structure of jump training in volleyball. Eur. J. Sports. Sci. 3. 1-10. 
Zapletalová, Ludmila. Volejbal: učebné texty pre školenie trénerov I. triedy. 1. vyd. Bratislava: Peter Mačura - PEEM, 2001. $171 \mathrm{~s}$.

Zvonař, M., Pavlík, J., Sebera, M., Vespalec, T., Štochl, J. (2010) Vybrané kapitoly z antropomotoriky. Brno, Masarykova univerzita, $86 \mathrm{~s}$. 